\title{
Reklamlarda Annelik Miti: Özel Gün Reklamı Olarak "Anneler Günü" Reklamlarının Analizi
}

\author{
DOI: 10.26466/opus.650356
}

*

\author{
Didem Zeynep Bayazit * \\ * Dr.Öğretim Üyesi, İstanbul Ticaret Üniversitesi İşletme Fakültesi, İstanbul / Türkiye \\ E-Posta: zbayazit@ticaret.edu.tr \\ ORCID: 0000-0003-3884-7349 \\ Öz
}

Günümüzde, çoğu perakendeci trafik arttırıcı iletişim stratejilerinde motivasyon aracı olarak özel gün kutlamaların kullanmaktadır. Özel günler arasında yer alan 'Anneler Günü', tüketicilerin hediye verme niyeti ile satın alma isteğini arttırmakta ve buna bağh olarak, markalar alışverişi canlandırmak ve tüketimi arttırmak için bu özel günlerde yoğun kampanyalar düzenlemektedirler. Özel gün reklamlarn tüketicilerin satın alma kararların etkilemekte, hediye veren ve hediye bekleyen arasındaki ilişkiyi bazı norm ve toplumsal değerler ışı̆̆ında yönetmektedir. Bu çalışma, iletişim çabalarında markaların özellikle Anneler Günü'ne özel yarattıkları reklamlarda annelik mitini nasil kullandıkların incelemektedir. Çalışma, özellikle Nisan sonu-Mayıs ayı 2019 tarihleri arasında Türkiye'de yayınlanan Anneler Günü reklamlarına odaklanarak, kolayda örneklem yöntemiyle belirlenen ve bu özel güne özgü reklam veren farklı sektörlerde faaliyet gösteren altı markanın dilsel ve görsel öğeler ışı̆̆ında reklamlarını analiz etmektedir. Sonuç olarak, literatürde 'Özel Gün' reklamları kategorisinde yapılacak olan gelecekteki çalışmalara ışık tutması amacıyla, toplumsal değerlerden oluşan mit ve kurguların reklamlarda anlaml kullanılmasının önemi vurgulanmakta ve marka ile özdeşleşen etkili iletişim stratejilerinin yapılandırılmasının uzun vadede markalara sürdürebilirlik kazandıracağı düşünülmektedir.

Anahtar Kelimeler: özel gün reklamı, annelik miti, dilsel/görsel öğeler 


\title{
Motherhood Myth in Advertising: An Analysis of "Mother's Day" Ads as Special Day
}

\begin{abstract}
Nowadays, most retailers use special day celebrations as a motivational tool in traffic increasing communication strategies. 'Mother's Day', which is one of the special days, increases the desire of consumers to make purchases with the intention of giving gifts and accordingly, brands carry out intensive campaings to revive shopping and accelerate consumption on those days. Special day advertisements affect consumers' purchasing decisions and manage the relationship between gift giving and gift waiting in the light of some norms and values. This study has examined how brands use the myth of motherhood, especially in advertisiments created specifically for Mother's Day. The study has focused on Mother's Day ads between the end of April and during May 2019, which were broadcast in Turkey. The advertisements of six brands operating in different sectors that were specific to this special day, which were determined by convenience sampling method, were analyzed in the light of linguistic and visual elements. As a result, in order to shed light on future studies to be conducted in the Special Day advertisiments category, the importance of meaningful use of the myths and fictions consisting of social values in ads is emphasized, and it is thought that constructing effective communication strategies identified with the brand will bring sustainability to brands in the long run.
\end{abstract}

Keywords: special day advertising, motherhood myth, linguistic/visual element 


\section{Giriş}

Günümüzde, kitle iletişim araçlarının etkisiyle tüketim kültürü sürdürülmekte, iletişim mesajları ile müşteriler alışveriş eğilimlerinde motive edilmektedirler. Bu araçların başında yer alan reklam, tüketim kültürü ile popüler kültürü bir arada yoğurarak kullandığı göstergeler ve imajlar sayesinde sembolik güç oluşturmakta (Featherstone, 1996, s.97) ve doğrudan ve/veya dolaylı anlamlar yaratarak ürün ve hizmetlerin tüketimine yönelik müşterileri etkilemektedir (Karaca ve Papatya, 2011, s.479). Özellikle Türkiye gibi kollektivist ülkelerde bir arada kutlanan özel günlerde markalar kullandıkları iletişim stratejileri ile tüketimi alevlendirmektedirler. Tüketimin doruk noktasına ulaştı̆̆ 1 özel günlerden biri olan Anneler Günü'nde tüketim çlgınlığı yaratılarak, dilsel ve görsel öğeler kullanılarak hediye vermenin önemi tüketicilere sunulmaktadır.

Bir özel gün kutlaması olarak Anneler Günü'nün bir hediye alma ritüeli haline dönüşmüş olması ve bu ritüelin toplumsal değerler ışığında oluşturulan annelik mitini temsil eden öğelerden oluşan özel gün reklamları aracılığıyla güçlenerek tüketim kültürü yaratması önemli bir konudur. Reklamlar aracılığılla tüketicilere hediye almaları gerektiği hatırlatılmaktadır. Reklam metinlerinde hediye ve değer verme kavramları işlenmekte, bugüne özgü bazı ürün gruplarını sunan markalar özellikle öne çıkmaktadır. Hediye tercihleri belirlenirken çoğunlukla annelik miti ev içi 'görünmez' emek gücü ile özdeşleştirilerek evle ilgili ürünler tercih edilmektedir. Duygusal yönü ön planda tutulan özel günlerde hediyeleşme ritüeli gün geçtikçe ticarileşmekte, perakende karını arttıran zamanlar olarak değerlendirilmektedir. Özel günlere verilen önemin artmasıyla insanlar daha fazla tüketime yönlendirilmekte ve toplumsal değerler değiştirilmektedir (Öztürk ve Temizkan, 2018, s.40).

Bankalar arası Kart Merkezi'nin (BKM) Nisan-Mayıs 2019 verilerine ilişkin raporuna göre, Anneler Günü'nü kapsayan 10-12 Mayıs hafta sonunda kartlarla yapılan ödemelerde bir önceki haftaya göre \% 71 artışla kuyumculuk sektörü en fazla artış görülen sektör olurken; \%26 artışla giyim ve aksesuar; \%25 artışla elektronik eşya sektörleri de ayın bir önceki hafta sonuna göre en fazla artışın görüldüğü diğer sektörler arasında yer almıştır. Bu rakamlara göre, Anneler Günü gibi özel günlerde, hediyeleşme ritüelini içeren konularda markaların tüketimi motive edici o güne özgü temalı iletişim stratejileri yaratmalarınn ne kadar önemli olduğu görülmektedir. 
Bu çalışmada, Türkiye'de yayınlanan Anneler Günü reklamlarına odaklanılmaktadır. Çalışma, 2019 yılı Nisan sonu-Mayıs ayı aralığında yayınlanan, kolayda örneklem yöntemiyle belirlenmiş farklı sektörlerde yer alan altı markanın dilsel ve görsel öğelerini dikkate alarak reklamlarını analiz etmektedir. Markaların bu özel gün temalı reklamları ile hedef kitlelere ne ifade etmek istendiğine vurgu yapılarak, içerik kurgusuna yorumlarla açıklık getirilmeye çalışılmıştır.

\section{Kavramsal Çerçeve}

Reklamlar; kullanılan imgeler bütünü ile gerçek dünyayı birleştirerek, iletiler yaratmaktadırlar (Kocabaş ve Elden, 2006, s.45-47). Tüketicilerden reklamda kendilerine sunulan imgeler gibi olmaları veya o içerikte davranmaları beklenmektedir. Reklam iletilerinde kullanılan imgelerin, sembollerin, dilin, imajların, renklerin, jest-mimiklerin, kodların ve ikonların açıkça olmasa da görsel ve/veya işitsel göstergeler aracllı̆̆ ile hedef kitlelere dolaylı olarak aktarılmaktadır. Genel olarak bakıldığında, reklamda ileti oluşturulurken anlam aktarımında görsel ve dilsel öğeler birbirini desteklemektedir (Küçükerdoğan, 2009, s.189; Snyder ve DeBono, 1985, s.586).

Williamson'a (2001, s.12) göre, reklamlar, sadece ürünlerin niteliklerine bağlı olarak satış sağlamak amaçlı değil, reklamı yapılan ürün/markanın hedef kitle nezdinde ne ifade edeceği ve ne şekilde ifade etmesi gerektiğine göre şekillenmektedirler. Kuşkusuz reklamın büyük bir bölümü mesajdır. Mesajlar biçim ve içeriklerle anlam bulurlar. Bunlar terminolojik olarak 'gösterenşeyler' ve 'gösterilen-düşüncelerden' oluşurak göstergeyi oluştururlar (Saussure, 1985, s.72). Reklamlarda, "düz anlam göstergenin açık ve bilinen anlamıdır, ilk çağrıştırdığıdır. Yan anlam ise, göstergenin kullanıcıların duygularıyla, heyecanlarıyla ve kültürel değerleri ile buluştuğu etkileşimidir", bu doğrultuda yorum, yorumlayıcıdan etkilenmektedir (Elden vd, 2005, s.482). Saussure (1985) dilsel çözümlemeyi göstergelere ait kodların çözümlenmesi olarak kabul etmektedir. Bu bağlamda, reklamda dil yorum bilimi yaratmanın temel öğesidir. Dilsel yaklaşım reklamın çerçevesini kullanabilen ancak yaratamayan bir anlam sistemidir. Dil, resimli göstergeler ile kaynaşarak bütünlüklü bir gösterge oluşturur. Reklamlarda kullanılan tüm formların içinde 
dil en ulaşılabilen ve gerçek dünyanın parçası olarak deşifre edilen bir göstergedir. Leech (1966, s.175-178) dil bilimini yaratıcı tekniklerden sayılan, şiirsel ahenk, ses, sözcük, tümce, nakaratlar, jest-mimik (sözsüz dil-tiyatro öğeleri), eğriteleme, benzetme ve dilsel sapmalar ile açıklamaya çalışmıştır. Dil, çoğu zaman çifte anlamlarla yüklü olduğundan saydam olarak nitelendirilmez (Saussure,1985, s.10). 'Saydam' anlam sözcüklerin anlamı iken, 'yorum bilimsel' anlam sözöcüklerin ima ettiğidir. Dil bir şeyi doğrudan anlatırken aynı zamanda yaşam alanlarına, toplumsal çevrelere ve 'şey'lere gönderme yaparak çok şey ifade etmektedir (Williamson, 2000, s.88-89).

Reklamda görsel iletilerin algılanma aşamasında bir diğer önemli teknik olan renk unsuru, hedef kitlenin duygu ve düşüncelerini yönlendirmede sıkça kullanılmaktadır. Reklamclar tarafından renk kullanımının önemi uzun yıllardan beridir bilinmektedir. Reklamlarda renk kullanım tekniği, tüketicilerin duygularını harekete geçiren ve ikna çabası yüksek, ürünlere prestij yükleyen hatta tüketicilerin ürünlere yönelik algısını istenilen şekilde yönetecek güçte bir doğaya sahiptir (Lester, 1966, s.40; Tucker, 1987, s.40). Reklamlarda renk kullanımı, özellikle bir ürün ile diğer şeyler arasında bağ kurmak için öncelikli olarak resimli reklamcllıta kullanılan bir tekniktir (Williamson, 2000, s.23). Williamson'a (2000, s.23) göre renk kullanımı kendi başına anlam ifade etmez ancak rengin gönderme yaptığ şeye göre anlamlılık oluşmaktadır. Renkler, görsel reklamların işlevinde içerik içinde uyumu sağlamada ve zıtlık etkileri yaratmada önemlidir (Taşkıran ve Bolat, 2013, s.57). Renkler, bir öyküyü anlatmaya, nesneyi nesneye bağlantılandırmaya, nesneyi bir kişiye bağlantılandırmaya ve hatta ürünler arasında farklılaştırmaya ve belirginleştirmeye yardımc olurlar (Williamson, 2000, s.20-26).

Reklamlar ürünlere imgeler vererek farklılık yaratma işlevini gerçekleştirmektedirler. Berger (2019, s.10), imge kavramını yeniden yaratılmış ya da yeniden üretilmiş bir görünüm olarak tanımlamakta ve her imgede bir görme biçiminin yatmakta olduğunu savunmaktadır. Bu anlayışla bakıldığında imge, görünmeyeni görünür kılarken aynı zamanda görünmeyeni içerikte saklayarak, izleyicinin bulmasını arzulamaktadır (Sayın, 2003, s.11). Bu yüzden imgelerin görünmeyen anlamları kültürden kültüre, nesilden nesile farklı algılanabilmektedir (Şimşek, 2006, s.70). Williamson (2000, s.73) reklam üretiminin maddi dünyanın kodlamalarıyla oluşturulduğunu vurgulamaktadır. Williamson (2000, s.76) bilmeceler diyarına benzettiği reklamların çözümlemesine yorum bilimsel bir yaklaşımla açıklık getirerek, reklamların 
gerçek dünya ile doğrudan bir ilişkiyle yeniden düzenlenmiş gerçekliğe yönlendirme yaptığını ve hedef kitleyi yeni anlamlar sistemi oluşturması için yönlendirmekte olduğunu savunmaktadır.

Reklamda kadın imgesinin kullanımı uzun yıllardır tartışılan ve kültürel olarak işlenen zengin semboller arasındadır (Frederick ve Roberts, 1997, s.173). Reklamlarda kadın imgesinin kullanımı çoğunlukla reklamın hedef kitlesinin kadın olmasından veya başkalarını etkileme ve ikna etme çabasından dolayı olduğu bilinmektedir (Altınel, 2002, s.76). Sıklıkla, reklamda kadın, belirli sosyokültürel role uygun kalıp ve sınırlar içerisinde yer almaktadır (Bal, 2014, s.61). Kadının doğası gereği olan durumu ile özdeşleşen annelik olgusu da yine aynı sınır ve yargılardan etkilenmektedir. Çoğunlukla reklamlarda; kadınlar anne, ev kadını ve eş rollerinin bileşimi ile özgür kadın imgesi arasında ikili temsili içerik olarak yer almaktadır (Timisi, 1997, s.36). Annelik durumu geleneksellik, fedakarlık, titizlik, özveri, ev merkezlilik gibi birtakım kodlar içermekte, tüketim davranışı olarak bakıldığında annelik miti söz konusu sıfatları yansıtan tüketim ve yaşam tarzını anlatmaktadır (Bal, 2014, s.62).

\section{Annelik Miti ve Reklamlardaki Temsili}

Reklamlarda çoğunlukla annelik kurgusu daha çok ataerkil değerlerden kaynaklanan toplumsal rol ve sorumluluklardan etkilenmektedir. Annelik miti ile eşleştirilen kadınlık durumu görünmez emek gücüne dayalı ev içi üretimi kapsamaktadır. Adeta bir zorunluluk olarak öne çıkan kadının mutlu anne olma durumu, kusursuz bir eş ve çekici olması ve ancak ev içi sorumluluklarını aksatmadığı durumda çalışmasının toplum tarafından kabul edilebileceği görüşü sıklıkla dile getirilmektedir (Karaca ve Papatya, 2011, s.482). Söz konusu reklam metinlerinde, annelik miti içgüdüsel olarak duygusallığı ön plana çıkartmaktadır. Erdoğan'a (2005, s.130) göre mit, gösterilen şeylerin ikinci düzey anlamını vurgulayarak doğallaştırılmaktadır. Barthes'a (1991, s.140-142) göre mit analizi, kapitalist çıkarları destekleyen düşünme şekillerini mitler haline dönüştürerek egemen fikirleri gerçeklik içinde meşrulaştırmaktır. Benzer anlayışla, reklam metinlerinde işlenen annelik miti ile merhamet, şevkat, fedakârlık gibi açık veya örtülü bir biçimde yer alan ifadeler doğallaştırılarak kullanılmaktadır. 
Reklamda bilgi iletmenin yöntemleri arasında metin ve görsel ögeler görülmektedir. Reklamdaki sözel ve görsel unsurlar okuyucunun duygularını ve inançlarını harekete geçiren göstergelerdir. Bu duygu, değer ve inançlar birtakım kodlarla metafor, gösterge ve simgeler aracılı̆̆ıyla işleme girmektedir (Berger 1991, s.125-126).

Dolayısıyla tam da bu noktada, geleneksel motiflerle donatılmıs, titizlik, fedakarlık, özveri ve kutsallık gibi çoğaltılabilecek niteliklerle donatılmış ‘annelik' kurgusunun reklamlar aracılığıyla tüketime ve yaşam tarzına yönelik bir meta haline geldiği görülmektedir.

Özel gün reklamları popüler kültürün tüketim kültürü ile birleşmesini sağlamakta başta hediyeleşmek yaptırımı ile karşı karşıya kalan tüketici bir harcama buketi ile ancak bu tip günlerin kutlanabileceğine inandırılmaktadır (Aydın, 2016). Birine hediye verilmesi eylemi nesnenin seçimi, transferi ve sonrasındaki değerlendirme sürecinden oluşmaktadır. Hediye verilen kişi ile sosyal bağ oluşturmak, geliştirmek veya sürdürmek isteyen bireyler, ilgili konudaki ilişkiye ait duygu ve değerlerini sembolize edecek uygun ürün/hizmeti seçmekte yoğun bir çaba içerisindedir (Pandya ve Venkatesh, 1992, s.150; Akgül, 2014, s.81). Buna bağl olarak, yaşanılan toplumsal değerlere ilişkin oluşturulan reklam temaları ile ilgili özel gün kutlamasına ait bir hediyetüketim objesi, tüketicilerde alı̧veriş süresince sosyal, duygusal ve kişisel anlamda olumlu etkiler yaratsada, zorunlu kılınması adına risk algisını arttırmaktadır (Çakır vd., 2006, s.99).

Anneler günü özel günler arasında neredeyse bir ay boyunca (Nisan ortası-Mayıs ortası) hediye alma ritüelin yanında o güne özel yapılacaklar listesi ile markaların yoğun tutundurma stratejileri geliştirdikleri dönemlerin başında yer almaktadır. Anneliğin kutsallığı ve manevi anlamlar içermesi sebebiyle önemsenen Anneler Günü iletişim ve pazarlama stratejileri için büyük önem taşımaktadır (Öztürk ve Temizkan, 2018, s.41). Bugüne özel tasarlanan ürün/hizmetler gibi değer verildiğini hissettiren, çaba gösterilerek alındığı anlaşılan duygusal hediyeler yerini çoğunlukla fiyat promosyonu motivasyonuyla veya hediye verenlerin durumsal unsurlarından etkilenerek (zaman kısıtı gibi) alınan fonksiyonel ürünlere bırakmaktadır. Toplumsal öğrenilmiş ve dayatılan değerler sonucunda annelere atfedilen rollere uygun kategorideki ürün ve hizmetlerin reklamları bu dönemde ön plana çıkmaktadır. Gündelik hayatın doğal ve meşru kabul edilen kurgusundan uzaklaşan reklamlar ise, fark yaratarak hem marka imajını desteklemekte hem de hediye 
alanın kendisini daha iyi hissetmesini sağlayarak hediyeleşme sayesinde bağ kurulmasını güçlendirmektedir (Bal, 2014, s.83).

\section{Araştırmanın Yöntemi}

Bu çalışma, Türkiye'de 2019 yılında Anneler Günü kutlamalarını içeren Nisan sonu-Mayıs ayı tarihleri arasında yayınlanan reklamları incelemektedir. Çalışmada, teknolojik ev aletleri, perakende zinciri, ev tekstili gibi anneler gününde yoğun reklam veren, farklı sektörlerde faaliyet gösteren, altı markanın anneler günü temalı reklam metinlerindeki annelik mitinin işleniş biçimini, oluşturduğu söylemler üzerinden görsel ve dilsel öğeler bazında içerik analizi yapılarak incelenmesi amaçlanmaktadır. Örneklem oluşturulurken belirtilen tarihler arasında yayınlanan sadece Anneler Günü için tasarlanmış özel gün reklamları dikkate alınarak, tesadüfi olmayan örnekleme yöntemlerinden kolayda örneklem yöntemi kullanılmıştır.

Çalışma kapsamına söz konusu kategorilerin dahil edilmesinin nedenleri arasında bu ürün gruplarının anneler günü kampanyalarında ön plana çıması ve anneler günü için tercih edilen hediyeler kapsamında üst sıralarda yer alması bulunmaktadır.

Çalışmanın yöntemi çerçevesinde reklamlarda kullanılan görsel ve dilsel öğelerde yer alan anlam ve siluetine bakılacaktır. Bu kapsamda yanıt aranacak sorular; "markaların reklamlarında annelik kurgusunu nasıl konumlandırıldığı", "reklamlardaki annelik mitinin markaların ürün ve hizmetinin satışını artırmak amacıyla hangi anlamlar/çağrışımlar üzerinden kullanıldiğı"'dır. 


\section{Anneler Günü Reklamlarının Analizi}

\section{Reklam 1: Özdilek}

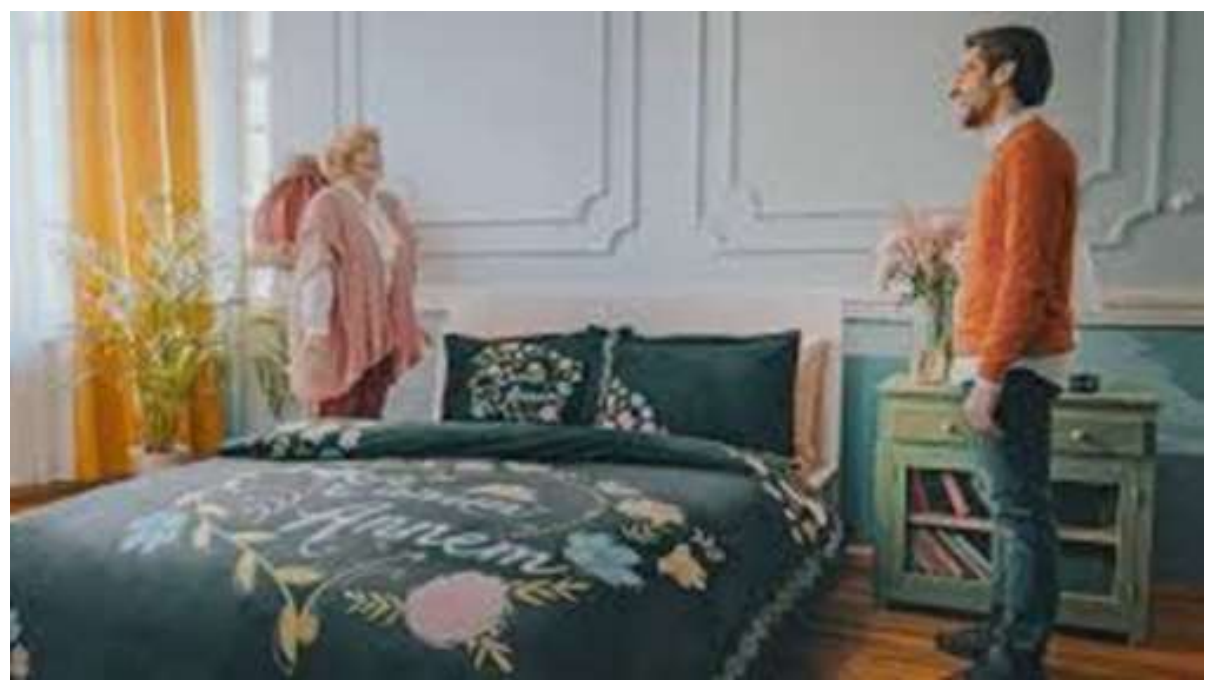

Görsel 1. Özdilek, “\#EnGüzelHediyemsin”- “Canım Annem”, 2019

Kaynak: (Youtube, 2019)

Reklamda Görüntüsel Göstergeler: Reklamın ilk karesinden itibaren, alt sol köşede Özdilek ev tekstili kurumsal yazı karakterinden oluşmuş logosu, sağ köşede ise özdelikteyim.com amblemi bulunmaktadır. Reklamın başlang1cında; turuncu kazaklı bir erkek ev ortamı görüntüsüyle döşenmiş bir mekana "annecim" diyerek giriş yapar. Mekan perde, koltuklar, yastık, çerçeveler, şamdan, çiçek ve konsol gibi, genel olarak bir evi, sıcak bir yuvayı çağrıştırdığ kim renk Özdilek turuncusudur. Koltukta oturan annesi olduğu anlaşılan kadın adama "senin arkanda ne var bakayım?" diyerek meraklı bir ifade ile soru sorar. Çocuk, annesine "Anneler Günün kutlu olsun" diyerek 'canım annem' yazılı Özdilek hediye paketini uzatır. Annesi gülümseyerek "ne gerek vardı oğlum! zaten sen benim en güzel hediyemsin" diyerek oğlunun yüzünü şevkatle okşar. Aynı anda, eş zamanlı olarak \#engüzelhediyemsin hashtag'1 ortaya çıkar. Annesine oğlu "sen her şeyin en güzeline layıksın, annem benim" diyerek paketi uzatır. O sırada rahatlatıc bir müzik başlar ve bu müzikle 
anne yatak odasında belirir. 'Canım annem' yazılı yatak takımını şevkatle okşayarak sererken son kare görülür.

Reklamda, anne kavramı ile özdeşleşen şevkat duygusu, oğluna ve ürüne dokunma/okşama metaforu ile kullanılmaktadır. Metafor bir sözün anlamı dışında başka bir söz olarak kullanılmasıdır. Reklamda dokunarak okşama eyleminin şevkat belirtisi olması metofor yaratmaktadır. Bu durum annenin evladına ve Özdilek markasına duyduğu sevgi bağını vurgulamaktadır. Son karede ise, oğlu annesinin yanında belirir. Orada olduğunu belirtici bir ses çıkararak annesinin huşu içinde Özdilek yatak takımını okşaması sırasında dikkatini çekmeye çalışır ve reklam anne, oğul ve yatak takımının yatağa serilmiş halini resmederek sonlanır.

Dilsel Göstergeler: Bu reklam metinsel olarak incelendiğinde, reklam dilinin net, sade ve anlaşlır olduğu gözlenmektedir. Reklamın içeriğine bakıldığında 'hediye' ifadesi çokca vurgulanmaktadır. Hatta hastag kullanılarak reklamda yer verilmiştir. Reklamda 'benim en güzel hediyem sensin' diyen annelere karşlık olarak, anneler gününde çocuklarının onlara hediye alarak bu özel günü kutlamaları gerektiği mesajı verilmektedir. Böylelikle, özel günde tüketim algısının oluşturulmasına katkıda bulunulmaktadır.

Bu reklamda ilk etapta mekan, ev ve anne ortamını bir arada çağrıştırırken, yan anlamda mekanda turuncu rengin (koltuk, yastık, perde vb.) hakim olması ve hediye veren çocuğun turuncu giyinmesi, anneye hediyenin Özdilek'ten verilmesinin mutluluk verici olduğu etkileşimini yaratmaktadır. Reklamda belirgin kadın imgesi, olgun yaşta bir anneyi göstermektedir. Kültürel boyutta değerlendirildiğinde, annenin çoğunlukla ev kadını rolünde olması beklendiğinden, tüketimi simgeleyen paketin ev ile ilgili bir hediye olmasına özellikle vurgu yapılan kodlar gönderilmektedir. 


\section{Reklam 2: Karaca Home}

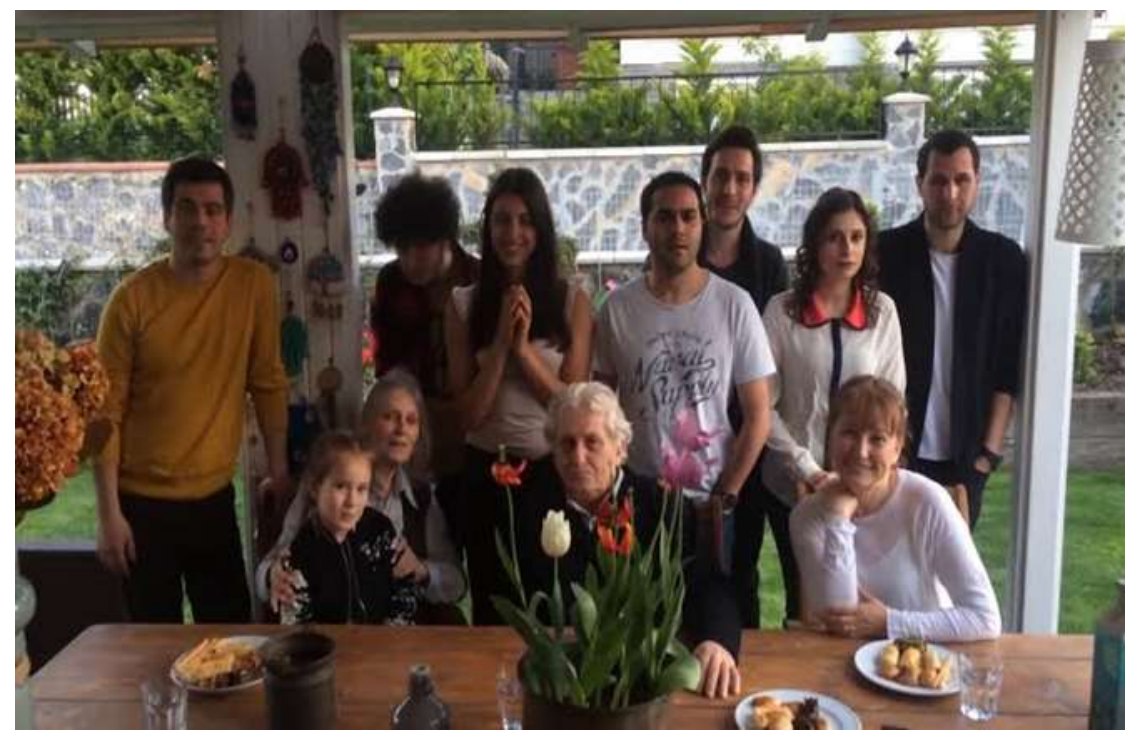

Görsel 2: Karaca Home, Bizlere Emeği Geçen Tüm Sevdiklerimiz- \#AnneOlunca",2019 Kaynak: (Youtube, 2019)

Reklamda Görüntüsel Göstergeler: Reklam ilk kareden itibaren aile ortaminda gerçekleşmektedir. Ortam, eve ait bir bahçede yer alan bir sofra düzeninde ve diğer aile fertlerinin bulunduğu çeşitli ev ortamlarında geçmektedir. Reklamda ana karakterler aile olarak işlenmiş, erkek, kadın, yaşlı ve çocuktan oluşan kalabalık bir bireyler topluluğu olarak görülmektedir. İletilmek istenen mesaj ailedeki her bir bireyin annelik misyonunu paylaşıyor olmasıdır. "Bizleri büyüten tüm aile büyüklerimizin (anne, baba, dayı, hala, teyze, amca vb.) anneler gününü" kutlamak gerektiği anlatılmaktadır. Reklamda, tüketicilerin birbirine bağlı bir aileye sahip olmasının motivasyonuyla "anne oluyorum!" müjdesinin aile içinde çok önemli ve mutluluk verici bir toplumsal değer olduğu öne çıkarılmaktadır.

Reklam, son karede yer alan beyaz arka planda öne çkan büyük puntolarla ve keskin yazı karakterinden oluşan Karaca Home logosu ve \#anneolunca hastag'i ile sonlanmaktadır. 
Reklamda özellikle amatörmüş gibi bir çekimin olması konunun aile kavramı ile ilintili olmasından ve doğallığa vurgu yapılmasından kaynaklanmaktadır. Aile olma kavramı, duygusal, sıcak ve samimi yönleriyle vurgulandığından, reklamda ev hali doğalını yansıtan mekan ve ortamlar tercih edilmiştir. Reklamdaki doğallık reklamın etkisini arttıracak değerdedir.

Dilsel Göstergeler: Reklamda kalabalık ve köklü bir aile temsil edilmektedir. Reklam hedef izleyici grubunu etkilemek üzere aile bağları, annelik ve gelenekler gibi değerleri bir arada sunmaktadır. Reklamlarda ağırlıklı kullanılan annelik kavramı kadın imgesi ile birleştirilirken, bu defa farklı olarak çocuğu büyüten kadın-erkek tüm aile bireyleri konu edilmiştir. Reklamda ilk göze çarpan özellik anne olmak, mutluk ve şaşkınlık duyguları ile gösterilirken, yan anlam olarak doğurganlık dışında, anneliği bir şekilde hissederek güvenle koruma iç güdüsüne sahip, anne hissi veren herkesin anneler günü olduğu vurgusu öne çıkmaktadır.

\section{Reklam 3: Arçelik}

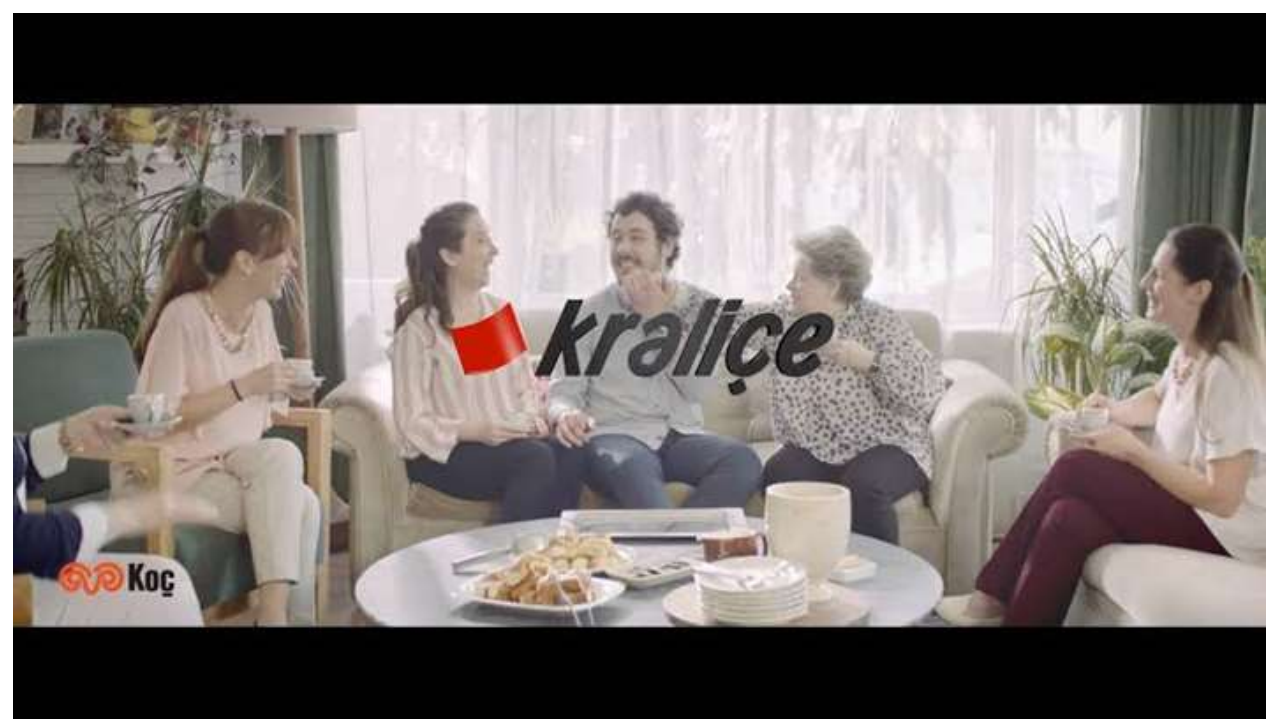

Görsel 3: Arçelik, “Tüm Annelere ve Anne Şefkati Esirgemeyenlere”, 2019

Kaynak: (Youtube, 2019) 
Reklamda Görüntüsel Göstergeler: Reklam, ilk kare kapıyı çalan bir adamın elinde bir buket çiçek ve kırmızı kurdeleli siyah (prestij) Arçelik paketiyle annesinin anneler gününü kutluması ile başlar. İçeri girince elinde hala tuttuğu paketin üzerinde Arçelik kurumsal logosu farkedilmekte, hatta kullanılan renkler marka çağrışımını ayrıca pekiştirmektedir. Ali (çocuk) hatırla sevgili şarkısı eşliğinde salonda diğer kadın akrabalarını görür ve mahçubiyet duyar. Reklamda kullanılan müzik bilinen 'hatırla sevgili' şarkının sözlerini adapte ederek, diğer kadın akrabaların da anne gibi şevkat gösterdiğini vurgulayan ifadelerden oluşmaktadır. Ali, durumu kurtarmak için annesine aldığı Arçelik kahve makinesini kullanarak salondaki tüm kadın akrabalarına kolaylıkla pişirdiği kahveleri servis eder ve yanlarına oturarak sohbete başlar. Eş zamanlı olarak kurumsal Arçelik logosu harfleri yer değiştirerek kraliçe kelimesine dönüşür. "Anne şevkatini üzerinizden hiç eksik etmeyen tüm kadınların anneler günü kutlu olsun" mesajı ile reklam son bulur. Son karedeki siyah-kırmızı logo üzerindeki değişim ile iletilmek istenen mesaj, Arçeliğin annelik miti olan kraliçelik olgusuna gönderme yapmaktadır.

Dilsel Göstergeler: Anneler gününe yönelik teknolojik ev aletleri reklam metinleri incelendiğinde zamandan tasarruf sağlayan, çocuklarına vakit ayırabilen ve fedakarlıklarıyla aile hayatını kolaylaştıran klişelere sıklıkla yer verilmektedir. Kadınların vaktinin büyük bir bölümünü alan ev işlerinin adeta bir mesai haline gelmesi ve popular kültür içerisinde kadınların anne olmalarından daha önemli herhangi birşeyin olmayacağını vurgulayan kutsal annelik miti, bu tip reklamlarla pekiştirilmektedir. Reklam, Ali karakteriyle bir erkeğin pratik ve hızlı bir şekilde kahve pişireceğini ve bu işin üstadı sayılacak kadınlara servis etmesini, toplumdaki rol ve kalıpların yeniden inşa edildiğine gönderme yapmaktadır. Konu edilen reklamda, özellikle ev içi emeğin kadında olması gerektiği genel inancına karşı çıkılması yan anlam oluşturmaktadır. Ayrıca, reklam özellikle anneliğin sadece kadın cinsiyeti ile bağdaştırıldığına dikkat çekmektedir. 


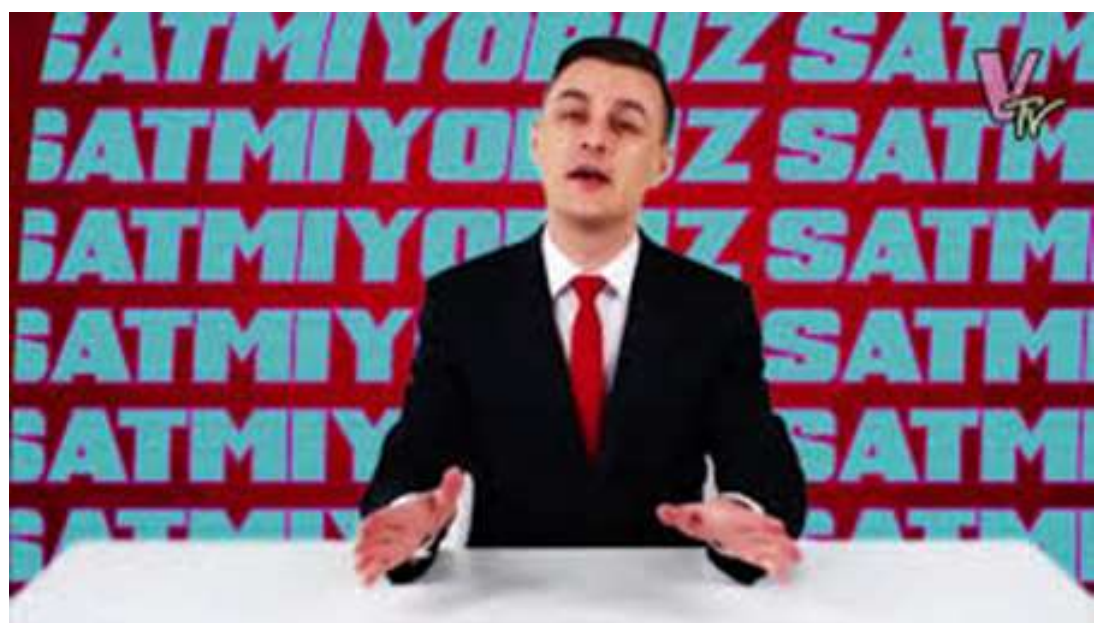

Görsel 4. Vestel, “\#AnnelerGünü hediyesi arayanlar, firsat ayă̆ınıza geldi\#EveDeğilAnneme",2019

Kaynak: (Youtube, 2019)

Reklamda Görüntüsel Göstergeler: Reklam, ilk karede tezatlıkla başlamaktadır. Geçmişteki anne siyah beyaz arka görüntüde daktilo yazan bir görsel ile gösterilirken, seslendirmede günümüz modern annenin sosyal medya kullanarak çocuğunu takip etmesi ve yorum yapmasına gönderme yapılmaktadır. İkinci karede, ev işi yapan anneye yardım etmesi düşünülen çocuğun yıkanmış perdeyi kornişe takma eyleminden bahsedilirken, birden ev aletlerinin (blender, çay makinesi, elektrikli süpürge gibi) tanıtımı ve terliklerin sadece misafirler için olmadığından bahseden bir anlatıma yer verilmiştir. Ev aletleri görüntüsü ekrana geldiğinde arka fonda parlak bir mavi renk gösterilerek Vestel'in teknolojik ve yenilikçi bir marka oluşuna gönderme yapılmaktadır. Vestel'in "terlik garantili anneler günü hediyesi, Vestel'de" söylemi korkutucu bir dil kullanılarak ve Vestel kırmızısı arka planda iç içe kalpler görüntüsüyle vurgulanarak, anneler gününde küçük ev aletleri alınmaması önerilmekte ve alındığında ise, kültürel anlamı iyi bilinen olumsuzluk/kızgınlık halinde annenin terlik firlatma eylemine gönderme yapılmaktadır. Hatta Vestel'in bugüne özel olarak ev aletlerini satmama misyonu, "satmiyoruz" söy- 
lemi ile defalarca kırmızı (Vestel) üzerine mavi (ev aletleri) yazılı olarak görüntüde vurgulanmakta ve "bakma öyle, sen de yap" söylemiyle kadının ev içinde görülmeyen değerini anlatmakta ve teknolojik ev aletleri ile özdeşen anne kavramından uzaklaştırmayı amaçlamaktadır. Ev işlerinin sadece kadına ait olduğuna değil, herkesin yapabileceğine yönelik motivasyon oluşturmak amaçlanmaktadır. Görüntülerde kullanılan daktilo, dantel perde, eski tip radyo ile geleneksel annelik miti olan ev hanımlı̆̆ çağrıştırılmakta; karşısında modern annenin beklentilerine yer verilmektedir. Reklamın başlangıc itibariyla, sağ üst köşede bulunan 'Vtv' görseli Vesteli simgelemektedir. Reklamın son karesi dahil olmak üzere bu görsel kullanılmıştır. Son karede "Sen De Yap" söylemi ile bitirerek "youtube.com/vestel/sendeyap" adresine yönlendirme yaparak, annenin değil 'senin' yaptı̆̆ın ev işlerini verilen linke yüklemeyi özendirmektedir. Vestel'in bugüne özel annelere Vestel markası dışında, başka hediyeler alınmasına yönelik harekete geçirici bu reklam içeriği, kendine güvenen bir marka algısı ile özdeşleşme yapılarak kullanılmaktadır.

Dilsel Göstergeler: Reklamda doğrudan pazarlamanın bir çeşidi olan telemarketing tutundurma dili kullanılarak, duyguları ve isteği harekete geçiren heyecanlandıran ve tetikleyen bir format tasarlanmıştır. Söz konusu tutundurma yönteminin doğası gereği, reklamın sonunda 'Sen De Yap' söylemi ile motivasyon yaratılarak, hedef kitlede merak uyandırılmakta ve hedef kitle youtube kanalına davet edilmektedir. Reklamda, annenin ev hanımlığıyla özdeşen teknolojik ev aletlerinin kullanımı, perde asılması gibi ev işleri konu edilerek annenin sürekli bunlar ile anılmasının mutsuzluk olduğu betimlenmiştir. Hatta reklam, annelerin ev işini hatırlatan hediyelere sinirlenmesini 'terlik fırlatmak' eylemi ile anlatmakta ve yan anlam oluşturmaktadır. Reklam satış tetikleme dilinden uzak, hedef kitle ile youtube kanalı aracılığıyla güçlü bir sosyal ilişki kurmaya yönelik bir bağ oluşturma amacındadır. Buna ek olarak reklamda, bilinen anneliğe yönelik duygusal farkındalığı arttırarak, hedef kitleyi annelerin işi olarak tanımlanan işleri yapmaya ve anlamaya yönelik örtülü bir amaç hedeflenmiştir. 


\section{Reklam 5: Boyner}

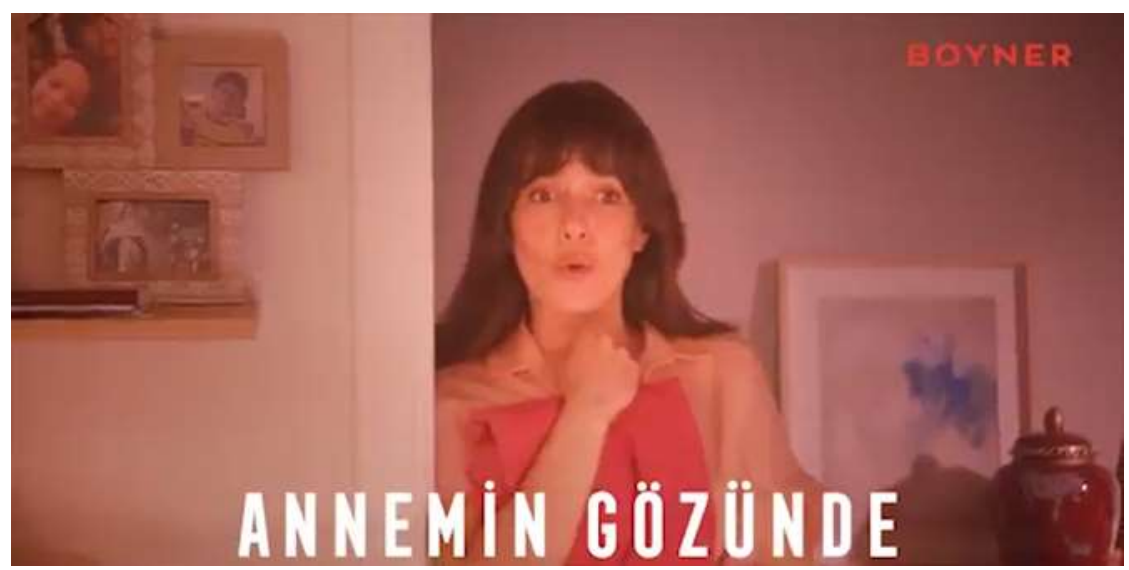

Görsel 5: Boyner, "Annelerin Gözünde Her Hediye Dünyalara Değer!"

"Gerçekte Olan - Annemin Gözünde", 2019

Kaynak: (Youtube, 2019)

Reklamda Görüntüsel Göstergeler: Reklam, kendi odasında pop müzikle amatör bir şekilde dans eden bir kız çocuğu ile başlamaktadır. Reklamda sağ üst köşede Boyner logosu reklamın sonuna kadar görülmektedir. Alt bantta, 1-12 Mayıs tarihlerinde geçerli olan kampanya bilgilerine yer verilmiştir. Ayna karşısında figürlerine bakan çocuğun gözlüklü, saçları toplu ve gösterişsiz giyimi ile çekingen tavırları dikkat çekmektedir. Çocuk dans ederken, oda içerisinde bulunan evcil köpeğin yüzünü kapatarak memnuniyetsiz bir tavır sergilemesi yan anlam oluşturarak, gerçekte çocuğun çokta başarılı dans etmediği ve iyi gözükmediği simgelenmektedir. Reklamda 'gerçekte olan' ve 'annemin gözünde' olan ikili karşıtlı̆̆ konu edilmektedir. Annenin odanın kapısına geldiğinde, çocuğunu gördüğü şekil ile gerçeklik arasında uçurumlar vardır. Annenin iftihar eden gözlerle bakması ve gurur ifadesi ile çocuğunun dansına hayranlığı reklam karesinde ekrana gelmektedir. Annenin gördüğü görüntü: çocuğu sahne sşıkları altında, arka planda yüksek sesli dijital bir müzik eşliğinde, çok iyi dans eden, estetik, kendinden emin bir görüntüye sahip profesyonel bir dansçıdır. "Her çocuk annesinin gözünde dünyalara değer" söylemi ile her annenin gözünde kendi çocuğunun mükemmel olmasına gönderme yapılmaktadır. Daha sonraki karede, çocuğun annesine beyaz 
üzerinde kırmızı Boyner kurumsal logosu olan bir hediye kutusunu vermesi ve annenin çocuğuna sarılması görülmektedir.

Reklamda çocuğuna sıkıca sarılmak metaforu annenin çocuğunu her durumda fedakarlık, sevgi ve şevkatle koruması, karşılıksız ve sonsuz destekleyici tavrı, "annelik" ile eşleşen güven duygusunu sağlamaktadır. "Şimdi ona dünyaları ver" söylemi eş zamanlı belirmektedir. Anneler Günü'nde, Boyner markasından alışveriş yapmayı özendirilerek, kampanya bilgileri ve ödeme koşullarına yer verilmektedir. Reklam son karesinde kırmızı Boyner logosu beyaz arka fon üzerinde ekran ortasında dikkat çekme amaçlı belirirken, altta Boyner grubu içinde satılan diğer markaların bilgisi gösterilmektedir.

Dilsel Göstergeler: Reklamda gerçekte olan ile anne gözünde hayal edilen arasında ikili karşıtlık kullanılmıştır. Buradaki zıtlık önce açık bir şekilde gerçeği sonrasında ise, annelik miti içerisinde yer alan koşulsuz sevgi ve her durumda destekleyici olma güdüsü ile hayal edilerek bir başka gerçek görsel göstergeler (dans, fiziksel görünüş, ortamda ki değişim vb.) üzerinden anlatılmaktadır. Dilsel göstergede ise, "her çocuk annesinin gözünde dünyalara değer" söylemi ile koşulsuz sevgi ve üst seviye değer biçme görsel göstergeler ile desteklenmektedir. Bu üst değer sunan anneye karşıllık olarak "şimdi ona dünyaları ver" söylemi ile Boyner markası dünya kadar değerli ve dünyaya eş değer görülmektedir. Reklam metninde başından sonuna kadar gerçeklik-hayal, Boyner-dünya, doğal-abartılı gibi karşıtlıklar kullanılmıştır.

\section{Reklam 6: Gitti Gidiyor}

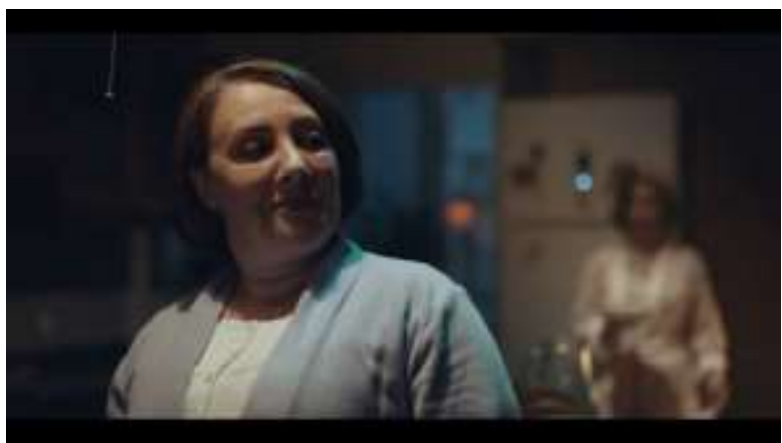

Görsel 6. GittiGidiyor, “Anneler Günü'nde Evladindan Hediye Almayan Annelere Öneriler",2019 (Youtube, 2019) 
Reklamda Görüntüsel Göstergeler: Reklamın başında dış ses "sevgili anneler" diye seslenmektedir. Evladından hediye almayan veya özensiz hediye verilen anneler gösterilmektedir. Birşeyin anlamını ifade etmek için ona ait başka birşeyin gösterilmesi anlamında kullanılan Metonomi kullanılmaktadır. Ekranda kökü üzerinde koparılmış bir çiçek gösterilerek- satın alınmadan herhangi bir bahçeden sökülmüş veya koparılmış bir çiçeğin özensiz hediyeyi çağrıştırması olarak ele alınmaktadır. Anneler, Anneler Günü'nün ertesi günü olan 13 Mayıs Pazartesi günü çocuklarından intikam almaları konusunda motive edilmektedirler. Reklamda, farklı birçok yaşam biçimine ait anne tipi gözlenmektedir. Kapı çalındığında, "evladınız için ceza ürünleri" söylemi ile 'gittigidiyor' kutuları kapıya gelir. Sözkonusu ürünleri satın alan annelerin ana amacı çocuklarına hayal kırıklığı yaşatmaktır. 2400vatlık bir elektrik süpürgesi, bazalı yatak, battal çöp poşeti, takılması zor bol ruletli bir perde, dondurma kabı içinde ayıklanmış bamya, çamaşır askısı vb. örnekler ceza teşkil eden hediyeler arasındadır. İntikam için sipariş edilen hediyelerin ev işlerinde kullanılan ürünlerden seçilmesi özellikledir.

Reklam \#yokyok hastag'i ve gittigidiyor logosu sağ üst köşede belirerek, "bulun en uygun cezayı seneye hediyesiz kalmayın" söylemi ile son bulur. Reklam son karesinde gittigidiyor uygulamasının AppleStore ve GooglePlaylar'den ücretsiz indirilebileceği bilgisine sağ alt köşede yer verilmiştir. Reklamda ev içinde sıklıkla kullanılan teknolojik ev aletleri, kültürel boyutta yer alan bize özgü evde çocuğun perde asması, boş dondurma kabına sebze konarak buzlukta tutulması ve çocukların çöpü çıarması gibi görsel göstergeler çocuklara ceza niteliğinde gösterilmektedir.

Dilsel Göstergeler: Reklamda hüzünlü bir müzik eşliğinde duygusal ama bir yandan da alaycı bir erkek dış sesi kullanılmaktadır. "Sevgili anneler evladınız size hediye almadı mı? ya da bir çiçekle günümü kurtardı?" söylemi yaşanan durumu provokatif bir dille ortaya koyarak, belki boş verecek olan annelerin farkındalığını ortaya çıkarmaktadır. "Bu yaptığı karşılıksız kalmamalı!" söylemi, duygusal davranışı tetikleyerek intikam duygusunu harekete geçirmektedir. Fedakar, koşulsuz seven, koruyan ve en önemlisi ev hanımı rolünde olması gereken klasik bir anne olarak görünen kadınlar, reklamda kinci, hinlik yaparak intikam alan farklı birçok role sahip annelere dönüşmüştür. Reklamda alışılagelmiş 'fedakar anne' metaforuna karşı özel gününde-Anneler günü- değer verilmediğini görerek 'intikamcı anne' bakış, 
mimik gibi sözsüz iletişim diliyle net bir şekilde yansıtılmaktadır. Düz anlam olarak, geleneksel bir anne-çocuk ilişkisinde rutin ev işlerinde yardım eden çocuk, yan anlam olarak, anneye hediye verilmediğinden intikam ile ev işlerinde cezalandırılan çocuğa dönüştürülmüştür. Anneler Günü hediye verilerek mutluluk ile eşleşirken aksi bir durumda, Anneler Günü'nde hediye alınmaması mutsuzluğa dönüşmekte, özel günde hediye beklentisi, verilmediği takdirde cezaya çevrilmektedir.

Bu reklamda, diğer reklamlardan farklı olarak 'Anneler Günü' teması gerek dilsel ve gerekse görüntüsel anlamda hediye yerine ceza kavramını ele almıştır. Gittigidiyor markasının sunduğu çok çeşitli ürün yelpazesi hediye olanağı yerini yaratıcı ceza ürünlerine çevirerek ters bir kurgu yaratılmaya çalışılmıştır. Alışagelmiş anne temalı reklam metinlerinin dişına çıkılmış ve reklam kurgusu Anneler Günü sonrasına odaklanarak yorumlanmıştır. Reklamda \#yokyok hastag'i ve ifadesi ile yapılan pekiştirmeyle, e-ticaretin en önemli özelliği olan ürün çeşitliliği konusunun altı çizilmekte ve bu pekiştirme ile tüketici zihninde en yaratıcı, en farklı ürün (ceza) algısının oluşumuna katkıda bulunulmaktadır.

Genel olarak değerlendirildiğinde, çalışmanın konusu olan altı markanın Anneler Günü temalı reklamlarının kategorilere göre dağılımı incelendiğinde; öncelikle ev tekstili, ev teknolojileri gibi ev içi kullanımı içeren ürün/hizmet markaları ve diğer çok çeşitli ürün kategorilerinin satıldığı dijital ve fiziksel perakende markaları bulunmaktadır. Özellikle, söz konusu kategorilerde ayn döneme ilişkin özel tasarlanan reklamlarda annelik miti ile özdeşleşen kavramlar ile içerik oluşturulmaktadır. Annelerin diğer rolleri d1şında ev hanımlı̆̆ rolünün öncelikli olması bu ürün kategorilerinin iletişim faaliyetlerinde önemli bir unsur oluşturmaktadır. Anneliğin kadınlık, şevkat, kraliçe, güven vermek, sahiplenmek, kutsallık, mutluluk ve mutsuzluk gibi duygusal faktörlere odaklı sergilenmesi bilinen bir gerçektir. Analizi yapılan reklam içeriklerinde annelik teması alışılagelmiş öğeler ile donatılırken, bazı markaların farklılık gösterdiği saptanmıştır. Karaca Home reklam içeriğinde annelik miti doğuran olmaktan çıkarılarak, sahip çıkan, fedekar olan ve emek vereren annelik duygusunu taşıyan kadın/erkek farketmeksizin her bireyi kapsar nitelikte kullanmış ve bu temanın bilinenden farklı işlendiği gözlemlenmiştir. Vestel markası diğer markalardan farklı olarak küçük ev aletlerini satmamak üzerine bir iletişim çalışması sergileyerek farklılaşmaktadır. Bu 
ürünlerin zaten alındığına hatta neredeyse temel ihtiyaç niteliğinde olduğuna dikkat çekilerek, hediyenin daha detaylı düşünülmüş, özellikli ve yaratıcılık sunan bir nitelikte olması gerektiği konusuna dikkat çekilmektedir. Gitti Gidiyor markası ise, iletişim çalışmasını sunduğu tüm ürün kategorilerini dahil ederek, satışa yöneltici stratejisini hediye karşısında ceza ürününü ortaya koyarak gerçekleştirmektedir. Dikkat çekici bu reklam örneğinde, iletişim stratejisinde farklılığ tezatlık ile birleştirmiş ve Anneler Günü'nün ertesi gününü hedef alarak, hediye almamış olan annelerin , kendilerine çocukların rahatsız edici nitelikte hediyeler alarak, intikam alması gerektiği vurgulanmaya çalışılmaktadır. Özetle, bahsi geçen reklam örneklerinde marka ile çağrışımları (renk, logo, amblem, web vb.) etkili kullanılmaya çalışılmışıır. Reklamların diline bakıldığında ise, sadelik ve anlaşılırlık ön planda iken, harekete geçirici, heyecanlı ve provakatif uslüplerinde kullanıldığı gözlemlenmektedir.

\section{Sonuç ve Öneriler}

Günümüzde popüler kültür öğelerini etkilemeye oldukça açı olan reklamlar, markalar ile tüketici arasında kurulan alışveriş ilişkisinden çok daha öte toplumsal yapıyı ve içinde yaşadığı kültüre yön vermektedir.

Türkiye'de çoğunlukla Batılı tüketim kalıplarından etkilenerek oluşturulan özel günler popülerleşmekte, adeta bir tüketim furyası yaratılmaktadır. Özel gün reklamlarının en önemlilerinden sayılan Anneler Günü reklamları annelik kurgusuna ilişkin sözcük ve göstergelerin tüketime nasıl yön verdiğini vurgulamaktadır. Annelik miti olarak gösterilen duygusal öğeler kullanılarak medyanın ve sistemin etkisi altında bırakılan tüketicide hediye beklentisine giren annelere yönelik yapılacaklar listesi baskısı yaratılmaktadır. Çoğunlukla, tüketici hediye temalı reklamlarda işlenen anlam ve/veya çağrışımlardan etkilenerek pasif konuma geçerilerek yönlendirilmektedir. Özellikle, bu tip günlerde normalde karşılaşabileceklerinden daha fazla sayıda reklam ve çeşitli promosyonlara maruz kalan tüketicinin, ister istemez bu dönemde ilgilenim düzeyi artmakta ve tüketicilere satın alma baskısı yaratılmaktadır. 
Tüketici davranışlarını etkileyen önemli unsurlardan biri, ekonomik özgürlüğ̈̈ne sahip olan kadının aile ve toplum içinde değişen rolü ve konumudur. Buna rağmen, konu annelik olgusuna geldiğinde ikileme düşen roller sebebiyle kadınlık yerini tema ile özdeşen fedakarlık, geleneksellik ve kutsallık gibi değerlere bırakmaktadır.

Literatürdeki çalışmalara bakıldığında özel gün reklamları ve annelik miti kullanımının reklam içeriğinde yer verilmesinin satın alma davranışını etkilediği yönünde birçok çalışma bulunmaktadır. Nitel çalışmalardaki değerlendirmeler ve bu çalışma göstermiştir ki; reklam içeriğinde klişe haline gelmiş kadının ev içi rolü ve anneliğin geleneksel kalıplar üzerinden değerler ile anlamlandırılması kullanımı devam etmektedir. Buna karşın; farklı anne tiplerinin reklamlarda kullanıldığı gözlemlenmektedir. Artık geleneksel kabuğunun dışında farklı değer ve davranış sergileyen anne kurguları markaları ayrıştırarak reklam kurgularına yönelik farkındalık yaratma ve dikkat çekme sağlanmaktadır.

İleriki çalışmalarda, ülkemizde özel günlerde toplumsal norm ve değerlerden oluşan belli başlı mitlerin kullanımının tüketiciler tarafından nasıl algılandığı ve satın alma davranışına nasıl etki ettiği konusu nitel ve nicel yöntemlerin karma bir şekilde kullanılması ile araştırılmalıdır. Çabuk sıkılan hep daha fazlasını isteyen tüketicinin, bu geleneksel anlayışın dışındaki yaklaşımlardan nasıl etkilendiği diğer bir çalışma konusu olarak incelenmelidir. Aynı zamanda giderek artan mobil uygulamalar gibi perakende teknolojileri olarak kullanılan tutundurma yöntemleri değerlendirilerek iletişim mecraları üzerinden karşılaştırmalı bir analiz yapılabilinir.

Markalar çoğu zaman yıllık satışları içerisinde en çok yoğunluğun yaşandığı bu tip özel günlerde, reklam mecrasını kullanırken tüketicilerin değissen istek ve değerleri doğrultusunda yaratıcı görsel ve dilsel öğeler kullanarak bambaşka yaklaşımlarla ilgi yaratmalıdır. Bu reklamların satışa dönüştürme etkisini arttırması yanında, marka imajını olumlu inşa edebilmesi açısından değerlendirilmesi önemlidir. 


\title{
EXTENDED ABSTRACT
}

\section{Motherhood Myth in Advertising: An Analysis of "Mother's Day" Ads as Special Day}

\author{
Didem Zeynep Bayazit \\ Istanbul Commerce University
}

In modern society, marketers and specifically retailers have mostly focused on increasing their longer-term productivity by using effective advertising strategies. For instance, in many retail firms, theme advertising, on special day celebrations, is used as a motivational tool to attract customers to the stores and increase store traffic. 'Mother's Day', which is one of those special days, increases the desire of consumers to make purchases with the intention of giving gifts and accordingly, brands are preferably conducting intensive campaings to revive shopping and accelerate consumption in those days. Especially, in collectivist countries such as Turkey in which special occasions are celebrated together, brands are fueling consumption by using attractive theme advertisements to effect consumers' purchasing decisions and manage the relationship between gift giving and gift waiting in the light of social norms and values. Mother's Day as other special days has a cyclical nature and consists of ritual artefacts and scripts. The language, color, image, gesture-mimics, and codes used in these theme advertisements are transferred directly and/or indirectly to the target audiences through visual, audio, textual and linguistic indicators. Consequently, advertising messages are of great importance in terms of form and content to promote gift interaction and to construct an idealized mother image. To analyze the ideologies and myth of motherhood, it is useful to understand that it is socially and culturally constructed. There is a somehow visible pressure on woman to limit their own desires but to spend more time to be the perfect housewife and a supporting/caring mother to their kids. The state of femininity paired with the myth of the maternity is normalized through advertisements with the pressure to match the invisible labor power, the perfect wife, the necessity to be attractive, and the best performing role of the housewife. 
This study has examined how brands use the myth of motherhood, especially in advertisiments created specifically for Mother's Day. The study has focused on Mother's Day ads between the end of April and during May 2019, which were broadcast in Turkey. The advertisements of six brands operating in different sectors that were specific to that special day, which were determined by convenience sampling method, were analyzed in the light of linguistic and visual elements. Findings of this study clarified the gender role of woman and mothering discourse by arguing that analyzed advertising contents suggested the form of motherings differently. However, what has characterized good motherhood was anchored in culture through advertisements. The common ground of the analyzed brands suggested the fact that the role housewife was the priority of mothers, apart form other roles, was an important factor in the communication strategies of those analyzed brands' product categories. Hence, especially on Mother's Day, brand selection as gifts had performance criteria of style, usefulness, quality and price which were transferred hedonically, symbolically and functionally to the advertisement content. It was also concluded as a known fact by most of the brands that the motherhood was displayed with emotional factors such as femininity, compassion, caring, protector, queen, resilience, holiness, happiness and/or unhappiness. Few brands, on the other hand, had used the motherhood myth independently of the woman in advertising content. These brands include every individual who had a sense of motherhood, regardless of whether they were women or men. Alternatively, another brand was focused on the next day of Mother's Day. In this remarkable advertisement example, it was targeted to mothers who had not received gifts should have taken a revenge from their kids by ordering 'disturbing gifts for kids' to their own. The brand distinguished from others by creating a contrast in a sense with its creative advertising strategy. In addition to all, another common feature of these brands is emphasizing the importance of mothers receiving gifts on mother's day and the need to be creative and thoughtful especially on this special day. Maternal myths and fictions, which exhibited different values and behaviors other than the traditional crust, were now distinguished among brands to raise awereness and attract attention.

To conclude, scholars have underlined that the use of emotional themes, symbols, and other elements in advertising clearly create positive 
reaction to a brand. Therefore, to create a distinct benefit for a brand or product category, emotions should be used to enhance the effectiveness of the advertising content. In order to shed light on future studies to be conducted in the Special Day advertisiments category, the importance of meaningful use of the myths, fictions, symbols etc. consisting of social values in ads is emphasized, and it is thought that constructing effective communication strategies identified with the brand will bring sustainability to brands in the long run.

\section{Kaynakça / References}

Akgül, D. (2014). Hedonik (Hazcl) tüketimin özel günlerdeki alı̧̧eriş kültürü̈̈̈zerindeki etkisi ve ülkelerarası karşılaştırmalı bir araştırma. Yayınlanmamış Doktora Tezi, Erciyes Üniversitesi Sosyal Bilimler Enstitüsü, Kayseri.

Altınel, Y. H. (2002), Kozmetik reklamlarında kadın ve nesne ilişkisi. Kilad- Kocaeli Üniversitesi Illetişim Fakültesi Araștırma Dergisi, 1(1), 75-93.

Arçelik (2019). Tüm annelere ve anne şefkati esirgemeyenlere. Youtube [Video Blog]. 15 Mays 2019 tarihinde https://www.youtube.com/watch? $=\mathrm{eVQMed} 3 \mathrm{PYeY}$ adresinden erişildi.

Aydın, G.A. (2016). Popüler kültür ve reklam ilişkisi: Basılı reklamlarda 14 şubat sevgililer günü. Global Media JOurnal TR Edition, 6(12), 387-410.

Bal, S. (2014) Reklamların eskimeyen yüzü "muhteşem annelik"-Anneler günü reklamları örneği. İlef Dergisi, 1(2), 59-85.

Bankalararası Kart Merkezi [BKM] (2019). Mayıs- Nisan 2019 Raporu, 12 Eylül 2019 tarihinde https://bkm.com.tr/wp-content/uploads/2019/01/bkm verileri nisan bb.pdf adresinden erişildi.

Barthes, R. (1991). Mythologies (25.bs). (A. Lavers, Çev.), New York: Noonday Press.

Berger, J. (2019) Görme biçimleri (26.bs). (Y. Salman, Çev.). İstanbul: Metis Yayınları. Boyner (2019). Annelerin gözünde her hediye dünyalara değer! ‘Gerçekte olan annemin gözünde. Youtube [Video Blog]. 15 Mayıs 2019 tarihinde https://www.youtube.com/watch?v=iyHR0bwwL9Q adresinden erişildi.

Çakır, S.Y., Eğinli, A.T. ve Özdem, Ö.O. (2006). Hediye verme davranışı ve alışveriş merkezlerinde deneyim yaratma stratejileri: Sevgililer Günü örneği. İletişim Araştırmaları Dergisi, 4(1), 97-121.

Elden, M, Ö. Ulukök ve Yeygel, S. (2005) Şimdi reklamlar. İstanbul: İletişim Yayınc1lik. 
Featherstone, M. (1996). Postmodernizm ve tüketim kültürü. (M. Küçük, Çev.). İstanbul: Ayrıntı Yayınları.

Fredrickson, B. L. ve Roberts, T. A. (1997). Objectification theory toward understanding women's lived experiences and mental health risks. Psychology of Women Quarterly, 21, 173-206.

GittiGidiyor (2019). Anneler Günü'nde evladından hediye almayan annelere öneriler. Youtube [Video Blog] 15 Mayss 2019 tarihinde https://www.youtube.com/watch?v=hvv7dSACwrg adresinen erişildi.

Karaca Home (2019) Bizlere emeği geçen tüm sevdiklerimiz- \#AnneOlunca. Youtube [Video Blog], 15 Mayis 2019 tarihinde https://www.youtube.com/watch?v=7Zqos8BF2C adresinden erişildi.

Karaca, Y. ve Papatya, N. (2011). Reklamlardaki kadın imgesi: Ulusal televizyon reklamlarına ilişkin bir değerlendirme. İktisadi ve İdari Bilimler Fakültesi Dergisi, 16(3), 479-500.

Kocabaş, F. ve Elden, M. (2006) Reklamcılık. (9. bs). İstanbul: İletişim Yayınları.

Küçükerdoğan, R. (2009) Reklam nasıl çözümlenir?. İstanbul: Beta Basım.

Leech, G.N. (1966). English in advertising. London: Longman.

Lester, G. (1966). Status enhancement as a function of color in advertising. Journal of Advertising Research, 6, 40-44.

Özdilek (2019). \#EnGüzelHediyemsin- Canım annem. Youtube [Video Blog], 15 Mayıs 2019 tarihinde https://www.youtube.com/watch?v=2o39IB6toGk adresinden erişildi.

Öztürk, A. ve Temizkan, V. (2018) Tüketicilerin anneler gününde hediye satın alma davranışlarının sebepli davranış teorisi bağlamında incelenmesi. EKEV Akademi Dergisi, 22(76), 37-56.

Pandya, A. ve Venkatesh, A. (1992). Symbolic communication among consumers in self-consumption and gift giving: A semiotic approach. Advances in Consumer Research, 19, 147-154.

Saussure F.D. (1985). Genel dilbilimsel dersleri. (Berke V. Çev.). Ankara: Birey ve Toplum Yayınları.

Sayın, Z. (2003). Imgenin pornografisi. İstanbul: Metis Yayınları.

Snyder, M. ve DeBono, K.G. (1985). Appeals to image and claims about quality: Understanding the psychology of advertising, Journal of Personality and Social Psychology, 49(3), 586-597.

Şimşek, S. (2006). Reklamlar ve geleneksel imgeler. İstanbul: Nüve Kültür Merkezi Yayınları. 
Taşkıran, N.Ö. ve Bolat, N. (2013). Reklam ve algı ilişkisi: Reklam metinlerinin alımlanmasında duyu organlarının işlevleri hakkında bir inceleme, Beykent Üniversitesi Sosyal Bilimler Dergisi, 6(1), 49-70.

Timisi, N. (1997). Medyada cinsiyetçilik. Başbakanlık Kadının Statüsü ve Sorunları Genel Müdürlügüu, Ankara: TTK Basımevi.

Tucker, J. (1987). Pscyhology of color. Target Marketing, 10(7), 40-49.

Vestel (2019). \#AnnelerGünü hediyesi arayanlar, fırsat ayağınıza geldi-\#EveDeği1Anneme. Youtube [Video Blog], 15 Mayss 2019 tarihinde https://www.youtube.com/watch?v=Fdo3cEsT]NM adresinden erişildi.

Williamson, J. (2000) Reklamlarm dili: Reklamlarda anlam ve ideoloji. (Ahmet F. Çev.). Ankara: Ütopya Yayınevi

\section{Kaynakça Bilgisi / Citation Information}

Bayazıt, D. Z. (2020). Reklamlarda annelik miti: Özel gün reklamı olarak "anneler günü" reklamlarının analizi. OPUS-Uluslararası Toplum Araştırmaları Dergisi, 15(22), 1157-1182. DOI: 10.26466/opus.650306 